\title{
Antiviral activity of garlic extract on Influenza virus
}

\author{
Mehrbod P., Amini E., Tavassoti-Kheiri M.* \\ Pasteur Institute of IRAN (Influenza Unit)
}

\begin{abstract}
Influenza virus is the most important cause of annual morbidities and mortalities worldwide with numerous antigenic drifts and shifts. Inaccessibility to effective drugs and vaccines has made world health authorities to be interested in traditional medicine in order to prevent spread of the infectious agent. Garlic is one of the most famous of all plants in human history. It has been shown that garlic extract has various effects on different diseases. The aim of this study was to evaluate garlic extract antiviral activity against influenza virus in cell culture. To study the potential antiviral activity, MDCK (Madin-Darbey Canin Kidney) cells were treated with effective minimal cytotoxic concentration of the extract and $100 \mathrm{TCID}_{50}(50 \%$ Tissue Culture Infectious Dose) of the virus during infection at different time periods. The viral titers were determined by hemagglutination (HA) and TCID 50 assays. The antiviral effect of the extract was studied at 1,8 and 24 hours after treatment on the culture. To measure the amount of the viral genome synthesized at different times after treatment, RNA extraction, Reverse TranscriptionPolymerase Chain Reaction (RT-PCR) and free band densitometry software were performed. Although the precise mechanism has not been defined yet, it was found that garlic extract with a good selectivity index (SI) has inhibitory effect on the virus penetration and proliferation in cell culture.
\end{abstract}

Keywords: Influenza virus $\bullet$ Garlic Extract $\bullet$ MDCK $\bullet$ HA $\bullet$ RT-PCR

\section{Introduction}

I nfluenza virus is capable of causing respiratory diseases worldwide. This virus is constantly evolving and new antigenic variants give rise to epidemics and pandemics. Influenza virus is unique among respiratory tract viruses because of its considerable antigenic variations. These mutations make it extremely difficult to develop effective vaccines and drugs against the virus (2). Therefore it is an essential need to use some of the traditional medicines and combine them with modern medicine to inhibit the viral activity (10).

Garlic may be one of the most famous herbal remedies to be used by in human history- dating back to ancient cultures. Garlic has been an interesting plant for centuries as a medicinal panacea. Broad range of pathogenic organisms, including bacteria, fungi, protozoa and viruses have been shown to be sensitive to fresh crushed garlic (4). Fresh garlic

\footnotetext{
*Corresponding author: Tavassoti Kheiri M., Pasteur Institute of IRAN (Influenza Unit)

Email: mtkheiri@yahoo.com
}

extract with allicin as the main active component of it has been shown to have antiviral activity in vitro and in vivo. Its beneficial effects may be due in part to sulfur-containing compounds such as allicine, diallyl disulfide, diallyl trisulfide (6) that react with thiol groups of various enzymes which are critical for microorganism surveillance (1). Influenza virus surface glycoproteins are hemagglutinin (HA) and neuraminidase (NA). HA structure consists of $\mathrm{HA}_{1}$ and $\mathrm{HA}_{2}$ subunits linked by disulfide bond. In this study various biochemical, virological, and molecular techniques were used to evaluate the antiviral activity of the garlic extract on Influenza virus.

\section{Material and methods}

\section{Virus \\ Influenza $\mathrm{A} / \mathrm{New}$ Caledonia/20/99 $\left(\mathrm{H}_{1} \mathrm{~N}_{1}\right)$ standard virus was obtained from National Institute for Biological Standards and Control (NIBSC). The virus was grown in MDCK cells in presence of 2 $\mu \mathrm{g} / \mathrm{ml}$ of Trypsin TPCK (Sigma, St.Louis, MI).} Cell culture 
Continuous MDCK cells were grown in Dulbecco's Modified Eagle's Medium (DMEM) (ICN) containing $10 \%$ heat-inactivated Fetal Bovine Serum (FBS) (Gibco, Gaithersburg, MD), 100 Units/ml Penicillin G and $100 \mu \mathrm{g} / \mathrm{ml}$ Streptomycin (Sigma Co.) at $37^{\circ} \mathrm{C}$ in a humidified $5 \% \mathrm{CO}_{2}$ incubator.

\section{Garlic Extract}

Garlic extract was obtained from Shahed University. Briefly, the fresh garlic bulbs were stripped off the outer theca and then chopped, mixed and sterilized by filtration. The transparent extract was preserved at $4^{\circ} \mathrm{C}$ for further use.

\section{Cytotoxicity assay}

MDCK cells were seeded at $5 \times 10^{4}$ cells/well in 96well microplates, incubated for $24 \mathrm{~h}$ at $37^{\circ} \mathrm{C}$.

Different concentrations of the extract were added to the culture and incubated for $48 \mathrm{~h}$ at $37^{\circ} \mathrm{C}$ in presence of $5 \% \mathrm{CO}_{2}$.

The $50 \%$ cytotoxic concentration $\left(\mathrm{CC}_{50}\right)$, effective minimal cytotoxic concentration (EMCC) and viability of the cells were defined by the MTT method.

\section{MTT assay}

Colorimetric MTT assay was performed according to Levi Raphael, et al [8]. Briefly, yellow color of MTT (3- $\quad[4, \quad 5$-dimethylthiazol-2-yl]-2, 5-diphenyltetrazolium bromide, Sigma) is changed to purple by mitochondrial succinate dehydrogenase of living cells. The medium of the confluent cells was removed, then $100 \mu 1$ of $1 \mathrm{x}$ MTT was added to each well. Following incubation at $37^{\circ} \mathrm{C}$ with $5 \% \mathrm{CO}_{2}$ for $2 \mathrm{~h}, 100 \mu \mathrm{l}$ of acidic isopropanol was added and mixed to release the color from the cells. Optical density at $540 \mathrm{~nm}$ was measured using ELISA reader (Stat Fax-200).

\section{Inhibitory effect on the virus titer}

Equal volume of Influenza virus $\left(100 \mathrm{TCID}_{50}\right)$ and EMCC of the extract were mixed and incubated at $37^{\circ} \mathrm{C}$ for 1,8 and $24 \mathrm{~h}$. They were added to the cells with different multiplicity of infection (MOI). Following one hour incubation at $37^{\circ} \mathrm{C}$ unabsorbed viruses were removed, then the cells were washed with phosphate buffer saline (PBS) and TPCKcontaining medium was added $(100 \mu \mathrm{l} /$ well). After 48 $\mathrm{h}$ incubation at $37^{\circ} \mathrm{C}$, viability of the infected and non-infected cells was evaluated by MTT method. The virus titer was determined by HA assay and Karber formula. The viral RNA was extracted and amplified by RT-PCR and evaluated by band densitometry software.

\section{Percent protection}

2 IJV, Volume 2, Number 1, Winter 2008/Spring 2009
Percent protection of the extract was calculated by Anova test (Tukey) using viability of mock-infected and infected cells after $48 \mathrm{~h}$ exposure (8).

\section{Hemagglutination assay}

To evaluate presence of the virus in cell culture, serial dilutions of the culture media were added to 96-well U-shape microplates. Chicken red blood cells (cRBCs) $(0.5 \%)$ were added to each well. Following incubation at least for one hour at room temperature, precipitation of the RBCs demonstrated absence of the virus while hemagglutination indicated presence of the virus (5).

\section{RNA Extraction}

Viral genomic RNA was extracted from the infected cells using Viral RNA Extraction Kit (Qiagen,Hilden,Germany). Briefly, $70 \mu 1$ cell culture media was used and RNA was bound to glass fibers fixed in a column and finally was isolated and eluted in $30 \mu \mathrm{l}$ of elution buffer. Since influenza A virus was assessed in this study, influenza B virus was added to the samples as internal control $(70 \mu 1)$.

\section{RT-PCR}

Complementary DNA of the viral RNA was synthesized by cDNA synthesis Kit (Fermentas,Vilnius, Lithuania). Ten microliter RNA sample along with random hexamer primers and dNTPs mix were incubated at $56^{\circ} \mathrm{C}$ for $5 \mathrm{~min}$, added to a mixture of RNase free buffer using RT-kit. The cDNA products were stored at $-20^{\circ} \mathrm{C}$.

PCR

PCR reaction was performed as described by Shahidi, et al (7). Primers used in this study amplified NP gene of influenza $B$ and $M$ gene of influenza $A$.

PCR products were visualized on $1.5 \%$ agarose gel by ethidium bromide staining after electrophoresis.

\section{Semi-Quantitative analysis}

The end of exponential phase of the virus amplification cycles by Real-time PCR was determined at 24 cycles. PCR products were measured semi-quantitavely by determining band densitometry ratio using "Image Tool" software. 


\section{Cytotoxicity}

\section{Results}

The viabilities were evaluated by MTT method. The results showed that Garlic extract had no serious effect on viabilities of MDCK cells at concentration up to $100 \mu \mathrm{g} / \mathrm{ml}$. EMCC of the extract was determined $10 \mu \mathrm{g} / \mathrm{ml}$ through MTT standard curve by Anova test (Tukey) (Table1). It did not show any serious cytopathic effects on the uninfected cells as control while reduced CPE of the virus infected cells.

\section{Percent protection}

The extract was exposed to the infected cells and after 48 h viability of mock-infected and infected cells measured by MTT. Percent protection was obtained by analysis of MTT results using SPSS software version 11.0 (Table 2).

Table 1: Cytotoxicity of Garlic extract on MDCK cells (MTT test)

\begin{tabular}{|c|c|c|c|}
\hline VIRUS & $\overline{\mathrm{CC}_{50}}$ & \multicolumn{2}{|l|}{$\begin{array}{l}\text { EMCC } \\
\left(\mathrm{EC}_{50}\right)\end{array}$} \\
\hline $\mathrm{A} / \mathrm{H}_{1} \mathrm{~N}_{1}$ & $100 \mu \mathrm{g} / \mathrm{ml}$ & $10 \mu \mathrm{g} / \mathrm{ml}$ & 10 \\
\hline \multicolumn{4}{|c|}{$\begin{array}{l}\text { CC50: concentration which causes } 50 \% \text { cytotoxic } \\
\text { effect } \\
\text { EC50: concentration of the drug required to inhibit } \\
50 \% \text { of virus-induced CPE } \\
\text { SI: Selectivity Index: CC50/EC50 }\end{array}$} \\
\hline \multirow[t]{2}{*}{$\begin{array}{l}\text { Table } \\
\text { Values } \\
\text { experim } \\
\end{array}$} & $\begin{array}{l}\text { Percent prot } \\
\text { are averages } \\
\text { ents }\end{array}$ & $\begin{array}{c}\text { tion resu } \\
\text { of fou }\end{array}$ & $\begin{array}{l}\text { TT test) } \\
\text { ependent }\end{array}$ \\
\hline & \multicolumn{3}{|c|}{$\overline{\mathrm{MEAN}} \pm \mathrm{SD}$} \\
\hline TIME & Virus & \multicolumn{2}{|c|}{$\begin{array}{l}\text { Extract treated } \\
\text { Virus }\end{array}$} \\
\hline 1h & $0.156 \pm 0.018$ & 0.25 & \\
\hline $8 h$ & $0.175 \pm 0.023$ & 0.27 & \\
\hline & $0.168 \pm 0.029$ & 0.27 & \\
\hline
\end{tabular}

*: Significantly different values obtained for extracttreated compared to untreated samples $(p<0.0001)$.

It was found that extract-treated virus compared to untreated samples had significantly different MTT results using Anova test (Tukey) analysis ( $\mathrm{p}<0.0001)$.

\section{Hemagglutination assay}

Antiviral effect of the extract was determined against influenza A (H1N1) in different sets of experiments. Inhibitory effect of the extract was shown by reducing HA titer (Figure 1 and Table 3).

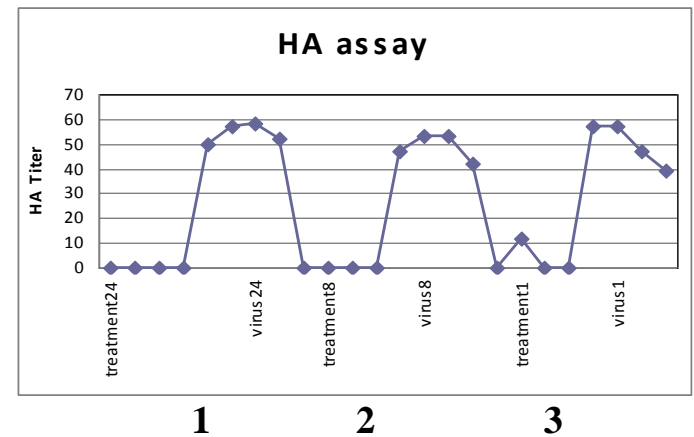

Fig. 1: HA of Garlic extract treated influenza virus A at different time periods.

Effect of the Garlic extract on HA titer of influenza virus at three time points: 1) $24 \mathrm{~h}, 2)(\mathrm{h}, 3) 1 \mathrm{~h}$, treatments.

Table 3: Antiviral activity of Garlic extract against influenza virus $A(\mathrm{H} 1 \mathrm{~N} 1)$ by $\mathrm{HA}$ test. Values are averages of four independent examinations for HA assay.

\begin{tabular}{|c|c|c|}
\hline \multirow[b]{2}{*}{ TIME } & \multicolumn{2}{|c|}{ MEAN \pm SD } \\
\hline & Virus & $\begin{array}{c}\text { Extract treated } \\
\text { Virus }\end{array}$ \\
\hline $1 \mathrm{~h}$ & $0.156 \pm 0.018$ & $0.253 \pm 0.013 *$ \\
\hline $8 \mathrm{~h}$ & $0.175 \pm 0.023$ & $0.275 \pm 0.051 *$ \\
\hline $24 \mathrm{~h}$ & $0.168 \pm 0.029$ & $0.274 \pm 0.063^{*}$ \\
\hline
\end{tabular}

Table 4: Quantitative analysis of RT-PCR products.

\begin{tabular}{|c|c|c|}
\hline \multirow[t]{2}{*}{ TIME } & \multicolumn{2}{|c|}{$\begin{array}{c}\text { BAND DENSITY } \\
(\text { MEAN } \pm \text { SD) } \\
\end{array}$} \\
\hline & Virus & $\begin{array}{c}\text { Extract treated } \\
\text { Virus }\end{array}$ \\
\hline 1h & $0.123 \pm 0.003$ & $0.077 \pm 0.002 *$ \\
\hline $8 \mathrm{~h}$ & $0.184 \pm 0.001$ & $0.097 \pm 0.001 *$ \\
\hline $24 h$ & $0.079 \pm 0.001$ & $0.042 \pm 0.002 *$ \\
\hline \multicolumn{3}{|c|}{$\begin{array}{l}\text { Gel electrophoresis of RT-PCR products of the vira } \\
\text { RNA after exposure to the extract (Mann-Whitney U } \\
\text { test) at time points. } \\
\text { Values are averages of four independent } \\
\text { examinations for RT-PCR. } \\
\text { * Significantly different values obtained for extract- } \\
\text { treated compared to untreated samples ( }<<0.0001) \text {. }\end{array}$} \\
\hline
\end{tabular}



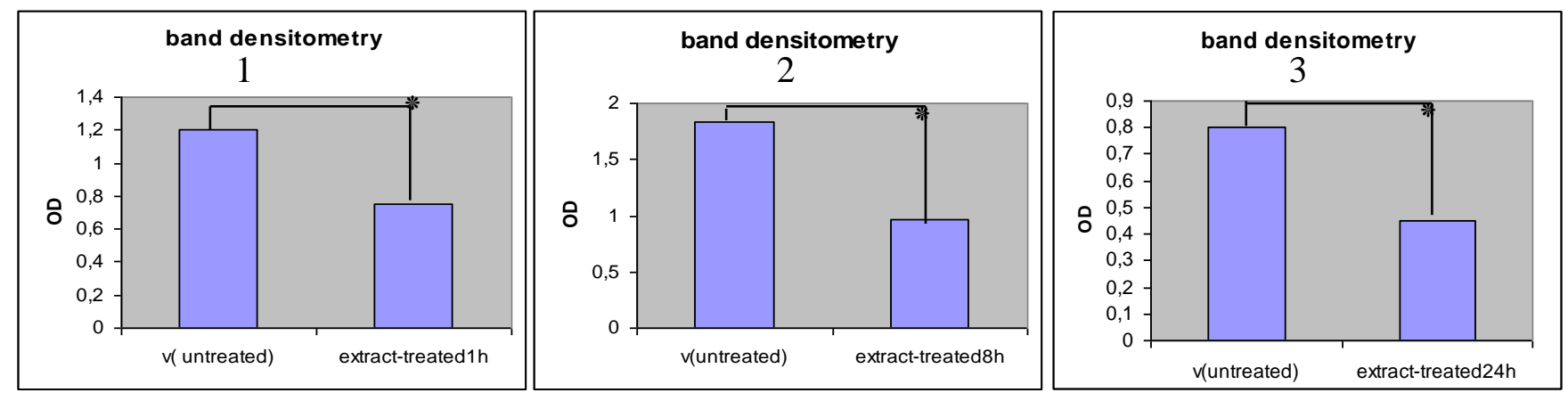

Fig. 2: Semi-quantitative analysis of the virus genome contents before and after treatment with the extract at 3 time points: 1) 1h, 2) $8 \mathrm{~h}, 3) 24 \mathrm{~h}$.

*: The results showed meaningful difference $(p<0.05)$ between exposed and non-exposed samples.

\section{Semi-Quantitative analysis}

The PCR was ceased at this cycle to be able to have semiquantitative results. The effect of the extract on the viral genome was shown by reduction in the content of the PCR products on gel electrophoresis (data not shown). Semi-Quantitative analysis using band densitometry on PCR products showed statically meaningful decrease in genome content after 1,8 and $24 \mathrm{~h}$ direct exposure of the extract to the virus by Mann-Whitney U test. (Fig. 2 and Table 4).

\section{Discussion}

As long as influenza virus remains a serious cause of disease, there will be a need to identify and develop some anti-influenza compounds with distinct mechanisms of action (11). Current therapeutic antiviral drugs have limited clinical efficiency and toxic side effects (3). Antiviral agents of plant origin are easily accessible, mostly nontoxic, and inexpensive (10). Garlic, with a long history of traditional medications, is shown to be effective against different microorganisms including viruses. Sulfur containing compounds in garlic extract such as allicine, diallyl disulfide, diallyl trisulfide and others (6) react with thiol groups of various enzymes, e.g. alcohol dehydrogenase, thioredoxin reductase and even disulfide bonds which are critical for microorganism surveillance (1).

We studied garlic extract's inhibitory effect against influenza virus $\mathrm{A} / \mathrm{H}_{1} \mathrm{~N}_{1}$. The virus was cultured on MDCK cells. $\mathrm{CC}_{50}$ value of this extract was obtained nearly $100 \mu \mathrm{g} / \mathrm{ml}$ by MTT method. The concentration of $10 \mu \mathrm{g} / \mathrm{ml}$ (EMCC) was found to inhibit virus growth to a large extent as was measured by reduction in HA titer and CPE induction.

Inhibition of influenza virus adsorption to MDCK cells and chicken red blood cells by the Garlic extract was estimated by MTT and HA methods. Its effect on the viral genome replication was determined by RT-PCR method. Our results showed concordance among methods used in this study; high percent protection following exposure of Garlic extract to the virus cell culture using MTT method is in concordance with reducing HA titer of the virus cell culture after incubation with this extract. The inhibitory effect of the extract was seen in RT-PCR products, too. By semi-quantitative analysis of PCR products with free band densitometry software, decrease in the content of the treatment bands was obvious in compared with untreated virus band.

For all three time periods of treatments, 1,8 and $24 \mathrm{~h}$ exposures, viral infectivity was reduced. Although it was effective and meaningful even after one hour contact compared with 8 and $24 \mathrm{~h}$ exposures. This may involve interference of viral membrane fusion by inhibition of penetration phase (9).

In conclusion, the biochemical and molecular methods used to evaluate of the antiviral activity of Garlic extract demonstrated that this compound could be suggested as a suitable potent antiseptic agent.

The molecular basis of antiviral effect of Garlic extract on influenza virus would be an interesting field for future studies. 


\section{Acknowledgement}

This study was supported by grant no. 392 from Pasteur Institute of Iran.

\section{References}

1. Ankri, S., and D. Mirelman. 1999. Antimicrobial properties of allicin from garlic. Microbes Infect 1:125-129.

2. Anonymous. 1995. Prevention and control of Influenza. MMWR 44RR3. CDC.

3. Gershengorn, H. B., G. Darby, and S. M. Blower. 2003. Predicting the emergence of drug-resistant HSV-2: new predictions. BMC Infectious Diseases 3:186-189.

4. Harris, J., S. Cottrell, S. Plummer, and D. Lloyd. 2004. Antimicrobial properties of Allium sativum (garlic). Applied Microbiology and Biotechnology 57:282-286.

5. Karber, G. 1931. 50\% endpoint calculation, Arch. Exp. Pharmak 162:480-483.

6. Schandalik, R., G. Gatti, and E. Perucca. 1992. Pharmacokinetics of silybin in bile following administration of silipide and silymarin in cholecystectomy patients.
7. Shahidi, M., M. T. Kheiri, S. Amini-BavilOlyaee, M. Hosseini, A. Moattari, M. Tabatabaeian, R. Bashar, R. SarramiForooshani, and F. Mahboudi. 2007. Molecular and phylogenetic analysis of human influenza virus among Iranian patients in Shiraz, Iran. J Med Virol 79:803-810.

8. Shigeta, S., S. Mori, J. Watanabe, S. Soeda, K. Takahashi, and T. Yamase. 1997. Synergistic anti-influenza virus A (H1N1) activities of PM523 (polyoxometalate) and ribavirin in vitro and in vivo. Antimicrob Agents Chemother 41:1423-1427.

9. Song, J. M., K. H. Lee, and B. L. Seong. 2005. Antiviral effect of catechins in green tea on influenza virus. Antiviral Res 68:66-74.

10. Vahabpour-Roudsari, R., M. ShamsiShahrabadi, S. H. Monavari, and S. E. Sajjadi. 2007. Evaluation of potential antiviral activity of hydroalcoholic extract of Lemon Balm L. against Herpes Simplex Virus type-I. Iranian Journal of Virology 1:28-32.

11. Wagaman, P. C., M. A. Leong, and K. A. Simmen. 2002. Development of a novel influenza A antiviral assay. J Virol Methods 105:105-114.

Arzneimittelforschung 42:964-968. 